\author{
Голодонюк О.М. \\ старший викладач \\ E-mail: kaf.mpit@gmail.com \\ Бузинський В.O. \\ магістрант \\ кафедра маркетингу підприємництва і торгівлі \\ Одеська національна академія харчових технологій \\ вул. Канатна, 112, м. Одеса, Україна, 65039 \\ E-mail: vbuzinsky@bk.ru
}

\title{
МАРКЕТИНГОВІ АСПЕКТИ РОЗВИТКУ ВІТЧИЗНЯНОГО КОНЬЯЧНОГО ВИРОБНИЦТВА В УМОВАХ КРИЗИ
}

Проаналізовано маркетингові підходи дослідження ринку при розробці та впровадженні товару, досліджено ринок алкогольних напоїв на прикладі коньяку, проаналізовано мікро- та макросередовище ПрАТ «Одесавинпром», проведено аналіз конкурентного середовища ПрАТ «Одесавинпром», проведено портфельний аналіз стратегічних зон господарювання ПрАТ «Одесавинпром», розроблено систему маркетингових стратегій для ПрАТ «Одесавинпром», розраховано ефективність впливу запропонованих заходів на основні показники діяльності підприємства.

Ключові слова: коньяк, ПрАТ «Одесавинпром», продукція, SWOT-аналіз, РEST-аналіз, новий продукт, новизна.

This work is licensed under a Creative Commons Attribution 4.0 International License http://creativecommons.org/licenses/by/4.0/

Постановка проблеми та їі зв'язок із важливими науковими та практичними завданнями. Інновації та інноваційний шлях розвитку є ключовим фактором успіху товаровиробника на ринку 3 гострою конкуренцією. Протягом тривалого часу світова економіка розвивалася переважно за рахунок екстенсивних факторів, а у виробництві домінували традиційні еволюційні процеси і явища.

Розвиток й ідентифікація сучасного виробництва повинні майже цілком будуватися на нових рішеннях в галузі технології, техніки, організаційних форм й економічних методів господарювання, тобто різних нововведеннях, впроваджених у виробництво.

Тільки радикальні заходи для впровадження нових технічних і технологічних рішень, сучасних виробничих процесів, здатних випускати конкурентоспроможні товари, дозволять економіці вийти з затяжної кризи і забезпечити Україні гідне місце у світовому співтоваристві. Це і є актуальністю обраної теми.

Аналіз останніх публікацій по проблемі. Останнім часом з'явилося досить багато робіт, присвячених теоретичним проблемам маркетингу, які відображають багато аспектів застосування маркетингу у формуванні товарного асортименту.

На жаль, значна частина публікацій спирається на іноземний досвід. Питання розвитку маркетингу й дослідження різних аспектів маркетингової діяльності розглянуті в чисельних працях вітчизняних і зарубіжних науковців: А. Павленка, А. Войчака, В.
Кардаша, В. Пилипчука, В. Герасимчука, С. Гаркавенко, Ф. Котлера, Дж. Еванса, І. Ансофа та ін.

Формулювання цілей дослідження. Мета статті - дослідити ринок коньяку 3 метою впровадження нового продукту - окреслила низку завдань:

- проаналізувати маркетингові підходи дослідження ринку при розробці та впровадженні товару;

- дослідити ринок алкогольних напоїв на прикладі коньяку;

- розробити рекомендації щодо розробки стратегії виведення нового товару на ринок;

- розрахувати ефективність запропонованих заходів.

Виклад основних результатів та їх обгрунтування. ПрАТ «Одесавинпром» - підприємство зі сторічною історією існування і славними традиціями виноробства. Підприємство, яке має багатий досвід виживання в умовах перебудови країни і економічної кризи. Це легенда міста Одеси, яка розташована на Французькому бульварі і спеціалізується на виробництві тихих вин, шампанського та коньяку.

Товарна лінійка коньяків нещодавно з'явилась в стратегічному портфелі підприємства i, як показав аналіз матриці БКГ, знаходиться в зоні «важких дітей», які потребують додаткових зусиль для зміцнення своїх позицій і переходу до квадранту «зірок».

Тому об'єктом дослідження став ринок виробництва коньяків. 
В теперішній час ринок коньяку в Україні переживає не кращий свій період. Політична ситуація в країні не тільки загострила економічну кризу, але й поставила багато підприємств, в тому числі харчової промисловості, на грань виживання. Не випадково, починаючи з 2012 року, спостерігається стійка тенденція до зниження обсягів продажу продукції коньячного виробництва (табл. 1).

Таблиця 1

Динаміка обсягів виробництва коньяку в Україні, млн. дал*

\begin{tabular}{|c|c|c|c|c|c|c|c|c|c|c|c|c|c|c|c|}
\hline 壱 & $\stackrel{\circ}{\circledR}$ & ¿ & $\stackrel{2}{\stackrel{2}{\Omega}}$ & $\frac{n}{2}$ & $\begin{array}{l}\stackrel{0}{\varrho} \\
=\end{array}$ & $\begin{array}{l}\mathscr{\infty} \\
\varrho\end{array}$ & ڤे & $\stackrel{\text { }}{2}$ & $\stackrel{8}{8}$ & $\stackrel{n}{8}$ & $\stackrel{\circ}{\circ}$ & $\overline{\bar{i}}$ & $\stackrel{2}{\stackrel{2}{2}}$ & $\stackrel{n}{2}$ & $\stackrel{\Delta}{\stackrel{i}{*}}$ \\
\hline $\begin{array}{l}\text { Обсяг вироб- } \\
\text { ництва }\end{array}$ & 0,2 & 0,9 & 1,2 & 1,1 & 1,6 & 1,4 & 1,5 & 1,6 & 1,9 & 2,4 & 2,8 & 3,6 & 3,9 & 3,1 & 3,0 \\
\hline $\begin{array}{l}\text { Темп росту } \\
\text { порівняно з } \\
1960 \text { p. }\end{array}$ & $X$ & 4,5 & 6,0 & 5,5 & 8,0 & 7,0 & 7,5 & 8,0 & 9,5 & 12,0 & 14,0 & 18,0 & 19,5 & 15,5 & 15,0 \\
\hline $\begin{array}{l}\text { Темп росту } \\
\text { порівняно } 3 \\
\text { попереднім } \\
\text { роком }\end{array}$ & $\mathrm{X}$ & 4,5 & 1,33 & 0,92 & 1,46 & 0,88 & 1,07 & 1,06 & 1,19 & 1,26 & 1,17 & 1,29 & 1,08 & 0,8 & 0,97 \\
\hline
\end{tabular}

*розраховано авторами на підставі джерел [9]

Причин ситуації, яка склалася, декілька:

- по-перше, коньяк не являється продуктом першої необхідності і в умовах різкого падіння реальних доходів населення розраховувати на збільшення попиту на цей товар не доводиться;

- по-друге, ріст імпорту коньяку. Через те, що держава прийняла указ про відміну ввізних мит на імпортну продукцію, урівнялися ціни на коньяк вітчизняного та імпортного виробників;
- по-третє, анексія Криму, яка призвела до втрати значної кількості споживачів коньяку, що також позначилося на обсягах виробництва і збуту цього напою.

Проведене маркетингове дослідження споживачів на основі анкетного опитування показало, що коньяк в рівній мірі вживають як чоловіки, так і жінки: співвідношення 53 \% до 47 \% відповідно (рис. 1).

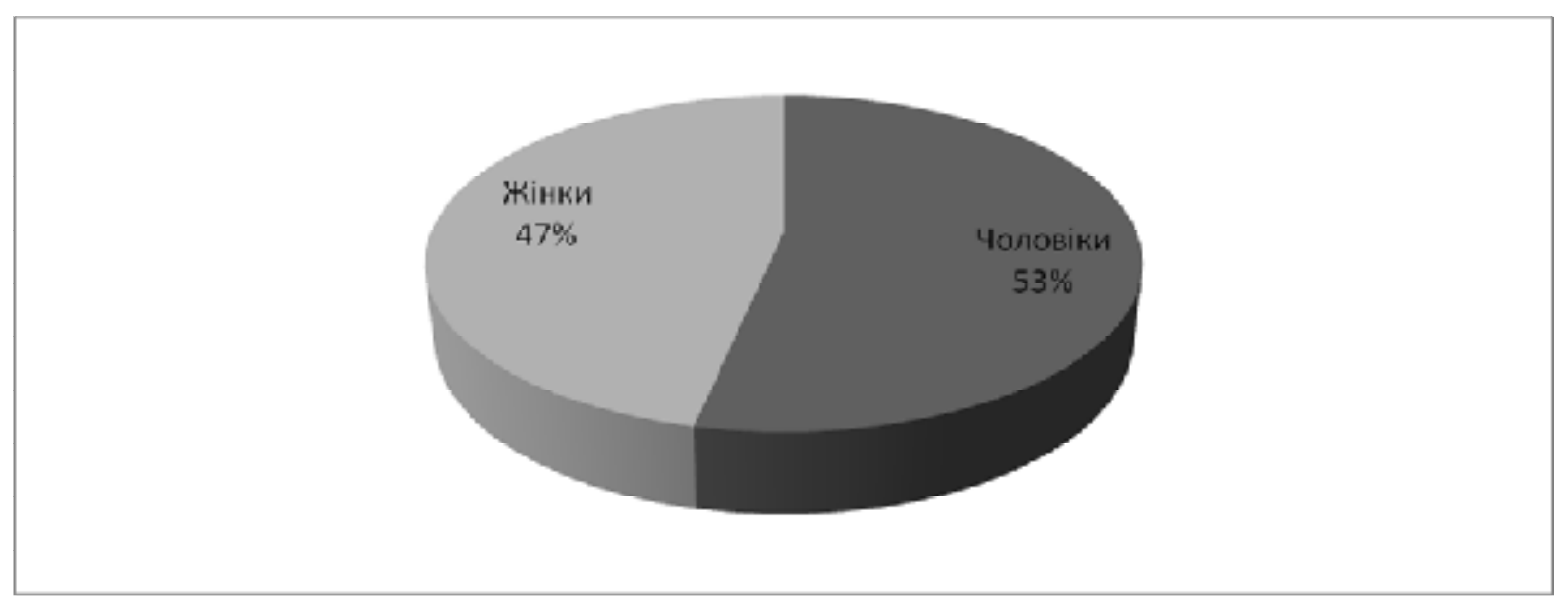

Рис. 1. Розподіл споживачів коньяку по статі*

*складено авторами на підставі анкетного опитування

Однак, більшість жінок відмовляються від купівлі коньяку через його жорсткий терпкий присмак. Їм не вистачає більш м'якого і лагідного напою, створеного на основі натуральних домішок, які б надавали цьому напою оригінальний смак.

Саме це побудило нас до створення і запровадження у виробництво нового виду продукції, а саме коньяку для жінок.

Для визначення параметрів на які потрібно звернути увагу при розробці та впровадженні нових видів продукції було розглянуто коньяк за кожним 3 п’яти рівнів товару за Котлером (табл. 2). 


\section{Ієрархія споживчої цінності коньяку*}

\begin{tabular}{|c|c|}
\hline Назва рівня & Характеристика \\
\hline $\begin{array}{l}\text { Перший рівень - } \\
\text { ключова цінність }\end{array}$ & $\begin{array}{l}\text { Коньяк - це алкогольний напій, призначений для підняття настрою і створення } \\
\text { доброзичливої ділової або святкової атмосфери в колі друзів, партнерів, рідних, } \\
\text { любимих та близьких людей. }\end{array}$ \\
\hline $\begin{array}{l}\text { Другий рівень - } \\
\text { основний товар }\end{array}$ & $\begin{array}{l}\text { Міцний алкогольний напій з характерним букетом і смаком, виготовлений купажем } \\
\text { коньячних спиртів, отриманих методом дистиляції коньячних виноматеріалів у } \\
\text { спеціальних мідних апаратах з фракціонуванням, витриманий не менше трьох років у } \\
\text { дубовій тарі або у нержавіючих емальованих місткостях із дубовою клепкою. }\end{array}$ \\
\hline $\begin{array}{l}\text { Третій рівень - } \\
\text { очікуваний товар }\end{array}$ & $\begin{array}{l}\text { Купуючи коньяк споживач очікує побачити у переважно прозорій пляшці напій } \\
\text { янтарно-золотистого кольору. Етикетку, з якої по спеціальним позначенням, можна } \\
\text { дізнатися про вік коньяку, а також про торгову марку, виробника, торговий знак, акциз } \\
\text { та ін. }\end{array}$ \\
\hline $\begin{array}{l}\text { Четвертий рівень - } \\
\text { додаткові характери- } \\
\text { стики }\end{array}$ & $\begin{array}{l}\text { - термін витримки; } \\
\text { - історичне походження; } \\
\text { - маркетингова легенда. }\end{array}$ \\
\hline $\begin{array}{l}\text { П'ятий рівень - } \\
\text { потенційний товар }\end{array}$ & При вживанні у помірних дозах , коньяк приносить користь для здоров’я. \\
\hline
\end{tabular}

\section{*авторська розробка}

Для визначення ризиків макро- та мікро середовища був проведений PEST-аналіз та надана кі- лькісна оцінка кожній окремій групі факторів (табл. $3)$.

Таблиця 3

Ступінь впливу факторів макросередовища на підприємство*

\begin{tabular}{|c|c|c|c|c|c|c|c|c|}
\hline \multirow{2}{*}{ Опис фактору } & \multirow{2}{*}{$\begin{array}{c}\text { Вплив } \\
\text { фактору }\end{array}$} & \multicolumn{5}{|c|}{ Експертна оцінка } & \multirow{2}{*}{$\begin{array}{c}\text { Середня } \\
\text { оцінка }\end{array}$} & \multirow{2}{*}{$\begin{array}{c}\text { Оцінка } 3 \\
\text { поправкою } \\
\text { на вагу }\end{array}$} \\
\hline & & 1 & 2 & 3 & 4 & 5 & & \\
\hline \multicolumn{9}{|c|}{ ПОЛІТИЧНІ ФАКТОРИ } \\
\hline $\begin{array}{l}\text { Майбутнє та нинішнє законодавство, } \\
\text { яке регулює правила роботи в галузі }\end{array}$ & 1 & 5 & 4 & 3 & 5 & 4 & 4,2 & 0,16 \\
\hline $\begin{array}{l}\text { Кількісні та якісні обмеження на ім- } \\
\text { порт }\end{array}$ & 2 & 1 & 3 & 2 & 3 & 3 & 2,4 & 0,18 \\
\hline Розвиток воєнних дій у країні & 1 & 2 & 1 & 1 & 3 & 3 & 2,0 & 0,07 \\
\hline Разом & 4 & & & & & & & 0,47 \\
\hline \multicolumn{9}{|c|}{ ЕКОНОМІЧНІ ФАКТОРИ } \\
\hline Рівень інфляції та процентні ставки & 3 & 5 & 5 & 5 & 5 & 5 & 5,0 & 0,56 \\
\hline $\begin{array}{l}\text { Рівень безробіття, розмір та умови } \\
\text { оплати праці }\end{array}$ & 3 & 5 & 4 & 4 & 3 & 4 & 4,0 & 0,44 \\
\hline Курси основних валют & 2 & 1 & 2 & 3 & 1 & 1 & 1,6 & 0,12 \\
\hline Разом & 8 & & & & & & & 1,12 \\
\hline \multicolumn{9}{|c|}{ СОЦІАЛЬНО-КУЛЬТУРНІ ФАКТОРИ } \\
\hline $\begin{array}{l}\text { Відношення споживачів до імпортних } \\
\text { товарів та послуг }\end{array}$ & 3 & 3 & 2 & 3 & 2 & 2 & 2,4 & 0,27 \\
\hline $\begin{array}{l}\text { Вимоги до якості продукції та рівню } \\
\text { сервісу }\end{array}$ & 1 & 5 & 5 & 5 & 5 & 5 & 5,0 & 0,19 \\
\hline Образ життя та звички споживачів & 2 & 3 & 4 & 5 & 5 & 4 & 4,2 & 0,31 \\
\hline Разом & 6 & & & & & & & 0,77 \\
\hline \multicolumn{9}{|c|}{ ТЕХНОЛОГІЧНІ ФАКТОРИ } \\
\hline $\begin{array}{l}\text { Рівень інновацій та технологічного } \\
\text { розвитку галузі }\end{array}$ & 3 & 3 & 1 & 3 & 1 & 2 & 2,0 & 0,22 \\
\hline $\begin{array}{l}\text { Законодавство в області технологіч- } \\
\text { ного забезпеченні галузі }\end{array}$ & 3 & 4 & 5 & 5 & 4 & 5 & 4,6 & 0,51 \\
\hline $\begin{array}{l}\text { Ступінь використання та впрова- } \\
\text { дження технологій }\end{array}$ & 3 & 3 & 4 & 5 & 2 & 4 & 3,6 & 0,40 \\
\hline Разом & 9 & - & - & - & - & - & - & 1,13 \\
\hline ВСБОГО & 27 & - & - & - & - & - & - & 3,49 \\
\hline
\end{tabular}

\footnotetext{
*авторська розробка
} 
3 отриманих результатів видно, що:

- технологічні фактори займають перше місце серед факторів розвитку підприємства та суспільства в цілому; технологія є одночасно внутрішньою змінною і зовнішнім фактором впливу на діяльність компанії;

- економічні фактори визначаються тим, що слабка економіка держави різко зменшує можливості організації на одержання кредиту й інших ресурсів, необхідних для нормального функціонування;

- соціально-культурні фактори впливають на підприємство прямо, адже саме від таких характеристик як народжуваність, смертність, структура сім’ї, рівень споживання та ін. залежить попит на продукцію підприємства, а отже, і на величину виручки, яку компанія може отримати в результаті своєї діяльносTi;

- політичні фактори мають значний вплив на підприємство, оскільки вони $є$ найважливішими факторами, які необхідно вивчати у першу чергу для того, щоб мати чітке уявлення про можливості успішної діяльності підприємства на ринку.

Проведений аналіз підтвердив, що підприємство ПрАТ «Одесавинпром» має усі шанси для створення і впровадження двох нових видів коньяку для жінок під торговою маркою «Француженка» (на відміну від торгової марки «Француз», призначену для чоловіків). До цієї торгової марки увійдуть два види продукції: «Брусничка на коньяку» та «Горобинка на коньяку». Їх особливостями буде неповторний м'який смак, який неодмінно оцінять жінки і який буде користуватися серед них попитом.

Брусниця 3 давніх часів булла однією з улюблених ягід північних народів, і не тільки їх. Ї̈̈, як і журавлину, і чорницю, відносять до цілющого сімейства ягід-лікарів. Існує легенда, що колись давнимдавно одна добра птиця вирішила принести людям 3 казкової країни воду безсмертя. Несла вона їі у своєму дзьобі. Але по шляху була ужалена осою. Від болю птах розкрив дзьоб і безсмертна волога впала на брусничні кущі. 3 тих самих пір листя брусниці вічнозелені, що свідчить про її цінність. Сама природа наділила цю ягоду великою кількістю вітамінів і мінералів, що допомагає людині захищати організм від хвороб та старіння.

Та це й не дивно. Адже крім здатності виступати в ролі ласощів - ці ягоди з таким же успіхом (а може, навіть, і з більшим) цілком можуть запобігти і зупинити багато людських хвороб.

Червона горобина добре відома як декоративна рослина. Завдяки її цілющим властивостям іiї здавна використовують у народній медицині.
Напої, що пропонуються відрізнятимуться своєю оригінальністю та користуватимуться попитом у всіх жінок в усьому світі. Благородно-м'який смак, який поєднує у собі ледве вловимі нотки коньяку та легку кислинку ягід, надасть яскраву виразність цим дивовижним напоям.

Для виготовлення будуть використовуватися виключно натуральні інгредієнти, тому впроваджує мий коньяк буде найвищої якості. Унікальна технологія переробки ягід дозволить максимально зберегти важливі для організму людини вітаміни.

«Брусничка на коньяку» та «Горобинка на коньяку» чудово підійдуть до десертів, в чай або каву, а також для виготовлення коктейлів. Ще більш вишукані вони в чистому вигляді: охолоджені та із льодом. Пити їх потрібно маленькими ковтками, як лікер - тоді напій повністю розкриє свій букет.

Для вирішення питання з обсягом виробництва нових видів продукції було розраховано ємність ринку збуту коньяку у м. Одесі.

Для визначення ємності ринку використано формулу, пов'язану з інтенсивністю споживання продукту:

$\mathrm{E}_{\mathrm{p}}=\mathrm{U}_{\mathrm{H}} *(1-\mathrm{a}) * \mathrm{~b} * \mathrm{c} * \mathrm{~d} * \mathrm{IC} \mathrm{IC}^{*} \mathrm{e}^{*} \mathrm{~K}_{\text {тижня }} * 1,1$

де $\mathrm{Ч}_{\mathrm{H}}$ - чисельність населення м. Одеси;

а - частка осіб, які не досягли 21 року;

b - частка осіб, які вживають коньяк;

c - частка осіб, які надають перевагу вітчизняній продукції;

d - частка жінок, які споживають коньяк;

ICП - інтенсивність споживання продукту;

е - ємність тари;

$\mathrm{K}_{\text {тижня }}-$ кількість тижнів у році;

1,1 - вивіз продукції в приміську зону.

В ході опитування були отримані наступні відповіді від споживачів відносно інтенсивності споживання коньяку:

1-2 рази на тиждень $\mathbf{- 2 5 , 4} \%$;

3-5 разів на тиждень $-\mathbf{7 , 4} \%$;

1 раз на 2 тижні - 39,7 \%;

1 раз на місяць - 27,5 \%.

Тоді, ємність ринку збуту коньяку в м. Одесі складе:

$\mathrm{E}_{\mathrm{p}}=1029 *(1-0,278) * 0,67 * 0,89 * 0,47 *(1,5 * 0,254+$ $+4 * 0,074+0,5 * 0,397+0,25 * 0,275) * 0,5 * 52 * 1,1=$ $=1029 * 0,722 * 0,67 * 0,89 * 0,47 * 0,94425 * 0,5 * 52 * 1,1=$ $=562,3$ тис. дал.

Для встановлення структури споживання коньяку було розроблено однофакторну функціональну карту (табл. 4).

Таблиця 4

Сегментування ринку збуту коньяку*

\begin{tabular}{|l|c|c|c|c|}
\hline \multirow{2}{*}{$\begin{array}{c}\text { Сегменти ринку по продукції (i) } \\
\text { (ознака - ціна) }\end{array}$} & \multicolumn{2}{|c|}{$\begin{array}{c}\text { Сегенти ринку по споживачу (j) } \\
\text { (ознака - рівень доходу) }\end{array}$} & \multirow{2}{*}{$\begin{array}{c}\text { Структура } \\
\text { споживання } \\
\left(\mathrm{K}_{\mathrm{j}}\right), \%\end{array}$} \\
\cline { 2 - 4 } & $\begin{array}{c}\text { Низький } \\
\text { (до 3000 грн.) }\end{array}$ & $\begin{array}{c}\text { Середній } \\
(3000-6000 \text { грн.) }\end{array}$ & $\begin{array}{c}\text { Високий } \\
\text { (більше 6000грн.) }\end{array}$ & 23,30 \\
\hline 1.Низький (до 90 грн.) & 70 & 10 & - & 48,05 \\
\hline 2.Середній (90-200 грн.) & 23 & 70 & 90 & 28,65 \\
\hline 3.Високий (більше 200 грн.) & 7 & 20 & 10 & 100 \\
\hline Доля сегменту по споживачу $\left(\mathrm{d}_{\mathrm{j}}\right), \%$ & 25 & 58 & 17 & \\
\hline
\end{tabular}

*складено авторами на підставі анкетного опитування 
Результати показали, що переважним сегментом є сегмент середньої цінової категорії.

Далі визначили ємність середньоцінового сегменту ринку по продукції:

$$
\mathrm{E}_{\text {сегменту }}=\mathrm{E}_{\mathrm{p}} * \mathrm{~K}_{\mathrm{i}}
$$

де $\mathrm{E}_{\mathrm{p}}$ - ємність ринку;

$\mathrm{K}_{\mathrm{i}}$ - структура споживання

$\mathrm{E}_{(\mathrm{c})}=562,3 * 0,4805=270,2$ тис. дал.

Враховуючу ситуацію, яка склалася на ринку коньяку та позитивний імідж продукції ПрАТ «Одесавинпром» плануємо відторгнути у конкурентів 8,62\%. Тоді об'єм власного виробництва коньяку складе:

$$
\mathrm{Q}=\mathrm{E}_{\mathrm{c}} * \mathrm{~K}_{\mathrm{вp}},
$$

де $\mathrm{E}_{\mathrm{c}}$ - ємність середньоцінового сегменту;

$\mathrm{K}_{\mathrm{вp}}-$ коефіцієнт відторгнення ринку.
$\mathrm{Q}=270,2 * 0,0862=23,3$ тис. дал.

Враховуючи, що старий асортимент залишиться в попередньому розмірі (13,3 тис. дал), на види продукції, що впроваджуються буде приходитись:

$\Delta \mathrm{Q}=23,3-13,3=10$ тис. дал.

За видами продукції, що пропонуються це відповідно складе:

- «Брусничка на коньяку» - 5,0 тис. дал.;

- «Горобинка на коньяку» - 5,0 тис. дал.

Щоб оцінити ефективність реалізації запропонованих заходів, необхідно розрахувати прибуток підприємства, який воно отримає у разі вдалого результату. Розрахунок представлений у вигляді таблиці 5.

Розрахунок показників ефективності від впровадження нової продукції*

\begin{tabular}{|c|c|c|c|}
\hline \multirow{2}{*}{ Показники } & \multicolumn{2}{|c|}{ Найменування нових видів продукції } & \multirow{2}{*}{ Загальна сума } \\
\hline & «Горобинка на коньяку» & «Брусничка на коньяку» & \\
\hline 1.Плановий об’єм виробництва, тис. дал. & 5,0 & 5,0 & 10,0 \\
\hline 2.Ціна, грн. & 1800 & 1800 & \\
\hline 3.Чистий дохід, тис. грн.. & 9000 & 9000 & 18000 \\
\hline $\begin{array}{l}\text { 4.3мінні витрати } \\
\text { 4.1.на одиницю продукції, грн.. } \\
\text { 4.2.на весь випуск, тис. грн.. } \\
\end{array}$ & $\begin{array}{l}950,98 \\
4754,9 \\
\end{array}$ & $\begin{array}{c}955 \\
4775 \\
\end{array}$ & $\begin{array}{c}1905,98 \\
9529,9\end{array}$ \\
\hline $\begin{array}{l}\text { 5.Маржинальний прибуток } \\
\text { 5.1.на одиницю продукції } \\
\text { 5.2. на весь випуск }\end{array}$ & $\begin{array}{l}849,02 \\
4245,1\end{array}$ & $\begin{array}{c}844,99 \\
4224,95\end{array}$ & 8470,05 \\
\hline 6.Постійні витрати на весь об’єм, тис. грн. & 2852,9 & 2865 & 5717,9 \\
\hline 7.Повні витрати на весь випуск & 7607,8 & 7640 & 15247,8 \\
\hline $\begin{array}{l}\text { 8.Точка беззбитковості } \\
\text { 8.1.в натуральному виразі, тис. дал. } \\
\text { 8.2.в вартісному виразі, тис. грн.. }\end{array}$ & $\begin{array}{l}3,36 \\
6048 \\
\end{array}$ & $\begin{array}{l}3,39 \\
6103 \\
\end{array}$ & \\
\hline $\begin{array}{l}\text { 9.Прибуток підприємства (неоподаткова- } \\
\text { ний), тис. грн.. }\end{array}$ & 1392,2 & 1360 & 2752,2 \\
\hline 10. Чистий прибуток & 1099,8 & 1074,4 & 2174,2 \\
\hline 11.Рентабельність продукції, \% & 18,3 & 17,8 & 18,05 \\
\hline
\end{tabular}

Таблиця 5

*авторська розробка

3 таблиці 5 видно, що виробництво 5 тис. дал. «Горобинки на коньяку» принесе прибуток 1392,2 тис. грн., і виробництво 5,0 тис. дал. «Бруснички на коньяку» - 1360 тис. грн.

Показники точки беззбитковості свідчать про те, що обсяг виробництва був обраний правильно, так як їх значення менше ніж запланований обсяг виробництва. Для порівняння:

«Горобинка на коньяку» ТБ $=3,36$ тис. дал $<\mathrm{Q}=5,0$ тис. дал;

«Брусничка на коньяку» ТБ=3,39 тис. дал $<\mathrm{Q}=5,0$ тис. дал.

Коньяк для жінок - це нова товарна лінія підприємства ПрАТ «Одесавинпром», тому на відміну від торгової марки «Француз», призначеної в основному для чоловіків, треба запропонувати реєстрацію нової торгової марки «Француженка» під якою буде вироблятися коньяк для жінок.
Розглянемо механізм виведення на ринок нової торгової марки і розрахуємо витрати по кожному з прохідних етапів.

Витрати на виведення нової торгової марки «Француженка» на ринок покажемо у вигляді таблиці 6. Отже, з проведеного розрахунку визначили, що витрати на створення та виведення на ринок торгової марки «Француженка» складуть 1007,1 тис. грн.

Розрахувавши вплив запропонованих заходів на основні показники ПрАТ «Одесавинпром» отримали наступні результати: чистий дохід фірми збільшився на 18000 тис. грн. або на 9,97\%. Прибуток від реалізації продукції збільшився на 1745,4 тис. грн. $(2752,2-1007,1)$ або на 19,57 \%. Витрати на 1 грн чистої виручки від реалізації зменшилися 0,5 коп., що $\epsilon$ дуже важливим для підприємства. Рентабельність продукції зросла з 5,19\% до 5,67 \%. 
Таблиця 6

Витрати на виведення ТМ «Француженка» на ринок*

\begin{tabular}{|l|c|c|c|}
\hline \multicolumn{1}{|c|}{ Етап } & Ціна, грн & Кількість, шт & Вартість, грн \\
\hline $\begin{array}{l}\text { 1. Послуги дизайнера по створенню } \\
\text { назви та зовнішньому оформленню }\end{array}$ & 24000 & - & 24000 \\
\hline 2. Розробка технологічної інструкції & 3000 & 2 & 6000 \\
\hline $\begin{array}{l}\text { 3. Реєстрація в Міністерстві аграрної } \\
\text { політики та продовольства України }\end{array}$ & 1500 & 2 & 3000 \\
\hline 4. Отримання штрих-коду & 160 & 2 & 320 \\
\hline 5. Отримання кведу & 150 & 200000 & 300 \\
\hline 6. Друк етикетки & 0,7 & 200000 & 760000 \\
\hline 7. Пляшка гвинтова і кришка під неї & 3,8 & 16667 & 60000 \\
\hline 8. Чорний ковпак & 0,3 & - & 50001 \\
\hline 9. Короб на 12 пляшок & 3 & - & 4350,05 \\
\hline $\begin{array}{l}\text { 10. Додаткова комплектація (акциз, } \\
\text { клей та ін.) }\end{array}$ & 5\% від загальної & комплектація & 1007121,05 \\
\hline Разом & - & 20000 \\
\hline
\end{tabular}

*авторська розробка

Висновки та перспективи подальших досліджень. Проведена наукова робота 3 дослідження ринку коньяку в Україні, вивчення смаків, запитів і переваг споживачів, проведення ситуаційного аналізу та визначення напрямків подальшого розвитку бізнесу, визначення ємності ринку і обсягів власного виробництва, грамотного просування товару і бренду на ринок є складовими успішної діяльності ПрАТ «Оде- савинпром». Таким чином, маркетингова діяльність в сучасному світі стає не тільки головною функцією управління будь-якого підприємства, але й запорукою його успішного розвитку.

Результатом проведених наукових досліджень стала нова коньячна продукція для жінок з натуральними домішками брусники і горобини під торговою маркою «Француженка».

\section{Лiтература}

1. Гаркавенко С.С. Маркетинг: [навч. посіб.] / С.С. Гаркавенко. - К.: Лібра, 1996. - 384 с.

2. Армстронг Г. Маркетинг. Загальний курс: [навч. посіб.] / Г.Армстронг, Ф. Котлер; пер. 3 англ. - М.: Видавничий дім «Вільямс», 2001. - 608 с.

3. Котлер Ф. Основы маркетинга / Ф. Котлер; пер. $з$ англ. - М.: Ростинтэр, 1996. - 704 с.

4. Герасимчук В.Г. Маркетинг: теорія і практика: [навч. посіб.] / В.Г. Герасимчук. - К.: Вища школа, 1994. - 327 c.

5. Хруцкий В.Е. Современный маркетинг: настольная книга по исследованию рынка: [учеб. пособ.] / В.Е. Хруцкий, И.В. Корнеева. - М.: Финансы и статистика, 1999. - 528 с.

6. Маркетинг: принципы и функции: [учеб.-практ. пособие для вузов] / под ред. Е.М. Азарян. - К.:

МЦВО Министерства образования Украины, НВФ «Студцентр», 2000. - 320 с.

7. Котлер Ф. Маркетинг менеджмент / Котлер Ф.; пер. с анг. под ред. Л.А.Волковой, Ю.Н. Каптуревского. - СПб: Питер, 2000. - 752c.

8. Історія виготовлення, виробництво та сучасний стан ринку коньяку [Електронний ресурс]. - Режим доступу: http://www.bestreferat.ru/referat-105437.html

9. Огляд ринку коньяку [Електронний ресурс]. - Режим доступу: http://www.yarmarka.net/

10.Буковинська бібліотека «Загальні поняття про середовище підприємства», [Електронний ресурс]. Режим доступу: http://buklib.net/books/22750/

11. Підручники онлайн «Метод анкетування», [Електронний ресурс]. - Режим доступу: http://textbooks.net.ua/content/view/103/11/ 


\author{
Голодонюк О.М. \\ старший преподаватель \\ E-mail: kaf.mpit@gmail.com \\ Бузинский В.O. \\ магістрант
}

кафедра маркетинга, предпринимательства и торговли

Одесская национальная академия пищевых технологий

ул. Канатная, 112, г. Одесса, Украина, 65039

E-mail: vbuzinsky@bk.ru

\title{
МАРКЕТИНГОВЫЕ АСПЕКТЫ РАЗВИТИЯ КОНЬЯЧНОГО ПРОИЗВОДСТВА В УСЛОВИЯХ КРИЗИСА
}

В статье рассмотрены маркетинговые подходы исследования рынка коньяка в случае разработки и внедрения новой продукции. Предложены рекомендации по разработке стратегий выведения нового товара на рынок. Рассчитана эффективность рекомендуемых мероприятий.

Инновационный путь развития является одним из решающих фракторов успеха любого производителя, который стремится к благополучному финансовому состоянию своего бизнеса и, как результат, получению желаемой прибыли.

ЧАО «Одессавинпром» является предприятием со столетней историей существования и славными традициями виноделия. Предприятие имеет огромнейший опыт выживания в условиях перестройки и экономического кризиса в стране.

Для разработки маркетинговых стратегий был изучен рынок, на котором работает ЧАО «Одессавинпром» и деятельность самого предприятия при помощи пяти уровней товара по Ф. Котлеру и PEST-анализа. Исследование подтвердило целесообразность внедрения в производство двух новых видов коньяка для женщин - «Брусничка на коньяке» и «Рябина на коньяке» под новой торговой маркой «Француженка».

Ключевые слова: коньяк, ЧАО «Одессавинпром», продукция, SWOT-анализ, PEST-анализ, новый продукт, новизна.

\author{
Holodonyuk 0. \\ Assistant \\ E-mail: kaf.mpit@gmail.com \\ Buzinsky V. \\ Undergraduate \\ Department of Marketing, Business and Trade \\ Odessa National Academy of Food Technologies \\ Kanatna str., 112, Odessa, Ukraine, 65039 \\ E-mail: vbuzinsky@bk.ru
}

\section{MARKETING ASPECTS OF DEVELOPMENT OF COGNAC PRODUCTION IN CRISIS CONDITIONS}

The article deals with marketing approaches to the research of the market of cognac in case of development and introduction of new products. Recommendations on the development of strategies for the introduction of a new product to the market have been suggested. The effectiveness of the recommended activities has been calculated.

The innovative way of development is one of the decisive factors in the success of any manufacturer who aspires to the prosperous financial condition of his business and, as a result, to obtain the desired profit.

PJSC «Odessanvinprom» is an enterprise with a century-old history of existence and famous traditions of winemaking. The enterprise has a huge experience of survival in the conditions of restructuring and economic crisis in the country.

In order to develop marketing strategies, the market, where the Odessanvinprom PJSC operates and the activities of the enterprise with the help of five levels of the product according to F. Kotler and PEST analysis have been studied. The research confirmed the expediency of introducing two new types of cognac for women - «Cowberry on Cognac» and «Ashberry on Cognac» under the brand name «Frantsuzenka».

Key words: cognac, PJSC «Odessavinprom», production, SWOT-analysis, PEST-analysis, new product, novelty. 


\section{References}

1. Harkavenko, S. S. (1996). Marketynh. K.: Libra.

2. Armstronh, H. (2009). Marketynh. Zahalnyi kurs. M.: Vydavnychyi dim «Viliams».

3. Kotler, F. (1996). Osnovы marketynha . M.: Rostyntэr.

4. Herasymchuk, V. G. (1994). Marketynh: teoriia i praktyka. K.: Vyshcha shkola.

5. Khrutskyi, V. E. (1999). Sovremennыi marketynh: nastolnaia knyha po yssledovanyiu rыnka. M.: Fynansы y statystyka.

6. Azarian, E. M. (2000). Arketynh: pryntsypы y funktsyy. K.: MTsVO Mynysterstva obrazovanyia UkraynыNVF «Studtsentr».

7. Kotler, F. (2000). Marketynh menedzhment. Pyter: SPb.

8. Istoriia vyhotovlennia, vyrobnytstvo ta suchasnyi stan rynku koniaku .. Retrieved 2017, from http://www.bestreferat.ru/referat-105437.html

9. Ohliad rynku koniaku. Retrieved 2017, from http://www.yarmarka.net/

10. Bukovynska biblioteka «Zahalniponiattia pro seredovyshchepidpryiemstva». Retrieved 2017, from http://buklib.net/books/22750/

11. Pidruchnyky onlain «Metod anketuvannia». Retrieved 2017, from http://textbooks.net.ua/content/view/103/11/

Received 02 August 2017

Approved 16 August 2017 Available in Internet 30.09.2017 